\title{
Influence of Perlite in Peat- and Coir- based Media on Vegetative Growth and Mineral Nutrition of Highbush Blueberry
}

\author{
Patrick H. Kingston \\ Department of Horticulture, 4017 Agriculture and Life Sciences Building, \\ Oregon State University, Corvallis, OR 97331
}

\section{Carolyn F. Scagel and David R. Bryla}

U.S. Department of Agriculture, Agricultural Research Service, Horticultural Crops Research Unit, 3420 NW Orchard Avenue, Corvallis, OR 97330

\author{
Bernadine C. Strik \\ Department of Horticulture, 4017 Agriculture and Life Sciences Building, \\ Oregon State University, Corvallis, OR 97331
}

Additional index words. container production, fertigation, salinity, soilless substrate, Vaccinium

\begin{abstract}
Peat and coir are commonly used for substrate production of highbush blueberry (Vaccinium sp.). Perlite is also typically added to improve drainage and stability of the media. The purpose of the present study was to determine how various combinations of each affect growth and nutrition in highbush blueberry. Two cultivars, 'Liberty' northern highbush blueberry ( $V$. corymbosum $L$.) and 'Jewel' southern highbush blueberry (interspecific hybrid of $V$. corymbosum $\mathrm{L}$. and $V$. darrowii Camp.), were grown for 3 months in media containing $0 \%, 10 \%, 20 \%$, or $30 \%$ perlite, by volume, and a 1:0, 2:1, 1:2, or $0: 1$ ratio of peat and coir. At 95 days after transplanting, total dry weight of the 'Liberty' plants was greatest in pure peat and progressively less as more coir or perlite was added to the media. Total dry weight of 'Jewel' also declined with increasing amounts of perlite but, in this case, was unaffected by the ratio of peat and coir. The response of the plants to perlite did not appear to be a function of $\mathrm{pH}$ or nutrition and was most likely related to the effects of perlite on media water relations. Response to peat and coir, on the other hand, may have been due to nutrition and salinity of the media. In both cultivars, a higher amount of peat in the media improved uptake of $\mathrm{N}, \mathrm{P}, \mathrm{Mg}$, and $\mathrm{S}$ and decreased uptake of $\mathrm{K}, \mathrm{B}, \mathrm{Zn}$, and Na. Coir, on the other hand, contained higher concentrations of $\mathrm{Na}$ and $\mathrm{Cl}$ than peat. These findings suggest that the use of high amounts of perlite in the media could be detrimental when growing highbush blueberry in substrate, and some cultivars may grow better in peat than in coir.
\end{abstract}

Container production is becoming an important competitive growing system for highbush

Received for publication 15 Oct. 2019. Accepted for publication $28 \mathrm{Feb} .2020$.

Published online 30 March 2020.

This project was funded, in part, by the U.S. Department of Agriculture (USDA) Agricultural Research Service (ARS), project number 2072-21000-048-00D. Mention of trade names or commercial products in this publication is solely for the purpose of providing specific information and does not imply recommendation or endorsement by the USDA.

This article is a portion of a thesis submitted by P.H.K. for the degree of Masters of Science in Horticulture at Oregon State University. We thank Jesse Mitchell and Suean Ott of the USDA for technical assistance and Jon Umble (Fall Creek Farm and Nursery) for his comments and advice for improving the manuscript. Current address for P.H.K.: Helena Agri-Enterprises LLC., 4195 Salem Industrial Drive NE, Salem, OR 97301.

D.R.B. is the corresponding author. E-mail: david. bryla@usda.gov.

This is an open access article distributed under the CC BY-NC-ND license (https://creativecommons. org/licenses/by-nc-nd/4.0/).
2001; Heiskanen, 1995a, 1995b; Londra, 2010; Londra et al., 2012). The amount of water retained by perlite will vary with particle size and is generally much higher for the coarse fraction $(0.5-1.0 \mathrm{~mm})$ than the finer fraction $(0.25-0.50 \mathrm{~mm})$ of expanded perlite used for horticulture (Burés et al., 1997).

Perlite is mined from rhyolitic volcanic minerals and, when used in media, is heated to 800 to $1100{ }^{\circ} \mathrm{C}$ to evaporate the water inside and expand the particles (Alkan and Doğan, 1998). Once expanded, the particles are very porous and light and provide a stable component in the media that is resistant to decomposition (Bar-Tal et al., 2019; Bilderback et al., 2005). Peat and coir, on the other hand, decompose and settle over time, eventually reducing the volume of the media (Bar-Tal et al., 2019). Economically, container production of blueberries requires that the plants remain in the same media for at least 4 years (B. Strik, personal observation). Therefore, growers are interested in media with high proportions of stable ingredients such as perlite for container production of highbush blueberry. The stability of perlite is relatively unaffected by acid or microorganisms, and therefore it can last for many years in the media (Bar-Tal et al., 2019). However, the use of high amounts of it can increase nutrient leaching from containers, decrease efficiency of fertilizer use, and negatively impact plant nutrition and growth (Bugbee and Frink, 1986; Munoz et al., 1993). There is also risk of toxic release of $\mathrm{Al}$ from perlite in media with low pH (Bar-Tal et al., 2019).

The objective of the present study was to evaluate the effects of using different amounts of perlite in peat- and coir-based media on growth and mineral nutrition of newly potted blueberry plants. We chose two cultivars for the study, including one northern highbush and one southern highbush blueberry. Both types of blueberry are commonly used for substrate production.

blueberry (Brazelton, 2017), but information on the best practices for the process is limited. For example, it is unknown which substrates are optimal for regional use in blueberry and whether there are cultivarspecific responses to different components of the media. Successful production of blueberry in a wide range of substrates would give growers flexibility in choosing media and mix ratios based on availability and economics (Mann, 2015).

Previously, we investigated how growth and nutrition of blueberry was influenced by altering the ratios of three common substrates, including peat, coir, and douglas fir bark, in media containing $10 \%$ perlite, by volume (Kingston et al., 2017). We found that the plants grew better in media with high proportions of peat or coir in the mix. However, it was unclear whether varying the amount of perlite in the media would have altered the response of the plants to peat and coir. Perlite has a much lower water holding capacity (WHC) than most organic materials and is often added to soilless media to increase drainage and porosity (Grillas et al.,

\section{Materials and Methods}

Experimental setup. Two cultivars, 'Liberty' northern highbush blueberry and 'Jewel' southern highbush blueberry, were obtained from a commercial nursery (Fall Creek Farm and Nursery, Lowell, OR) as 70-mL plugs and transplanted on 8 Apr. 2016 into 4.4-L pots [19.7 $\mathrm{cm}$ in diameter and $16.5 \mathrm{~cm}$ in height (\#2 Short); Anderson Pots, Portland, OR] filled with one of 16 different media treatments (one plant/pot). The treatments consisted of four rates of perlite (coarse expanded grade; Supreme Perlite Co., Portland, OR), including $0 \%, 10 \%, 20 \%$, and $30 \%$, by volume, each of which were combined in a cement mixer with different organic substrates, including sphagnum peat (Sun Gro Horticulture, Hubbard, OR), coir (coconut fiber; Pro Gro Mixes, Sherwood, OR), or a 2:1 or 1:2 mix of peat and coir. Each treatment was replicated five times for a total of 160 plants ( 2 cultivars $\times 4$ perlite treatments $\times$ 4 organic substrate treatments $\times 5$ replicates). The plants were in a temperature-controlled glasshouse at the USDA-ARS-Horticultural 
Crops Research Unit in Corvallis, OR (lat. $44^{\circ} 34^{\prime} 3^{\prime \prime} \mathrm{N}$, long. $123^{\circ} 17^{\prime} 19^{\prime \prime} \mathrm{W}$ ) and arranged in a randomized complete block design on two adjacent wire benches. Each bench was illumi- nated with two 1000-W high-pressure sodium lamps from 0700 to $2100 \mathrm{HR}$. A thermostat was set to cool the glasshouse at temperatures $>27^{\circ} \mathrm{C}$ and to heat it at temperatures $<15{ }^{\circ} \mathrm{C}$.
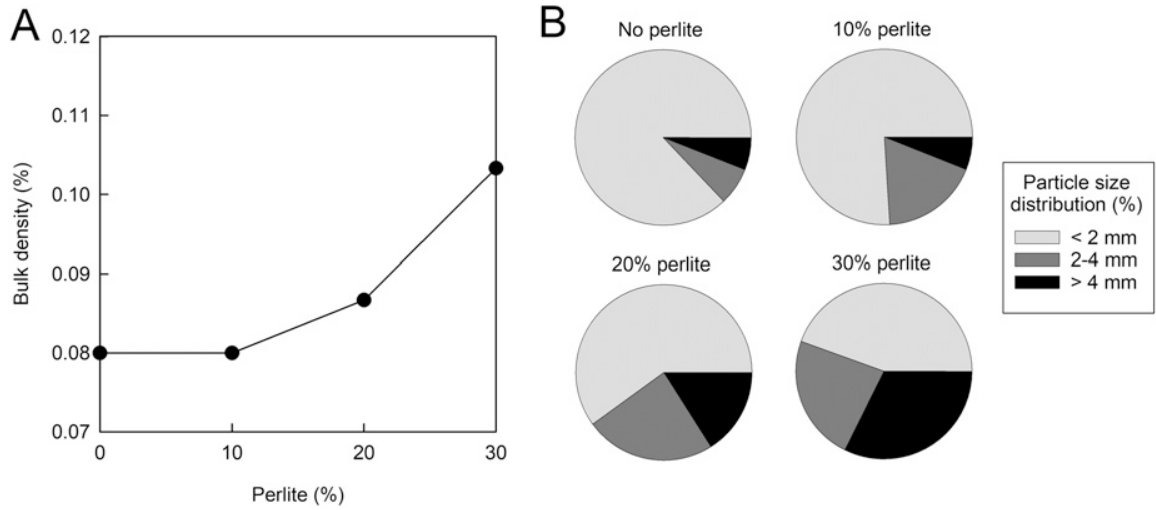

Fig. 1. (A) Bulk density and (B) particle size distribution in media with $0 \%, 10 \%, 20 \%$, or $30 \%$ perlite, by volume $(n=16)$. Means are pooled across treatments with different ratios of peat and coir in the media (peat, 2 peat: 1 coir, 1 peat: 2 coir, and coir). Spearman Rank Order correlations indicate that bulk density and larger particles $(2-4$ and $>4 \mathrm{~mm})$ were positively related to percent perlite in the media $(\rho=$ $0.47,0.86$, and 0.67 , respectively), while smaller particles $(<2 \mathrm{~mm})$ were negatively related to percentage of perlite $(\rho=-0.85)(P<0.05)$.
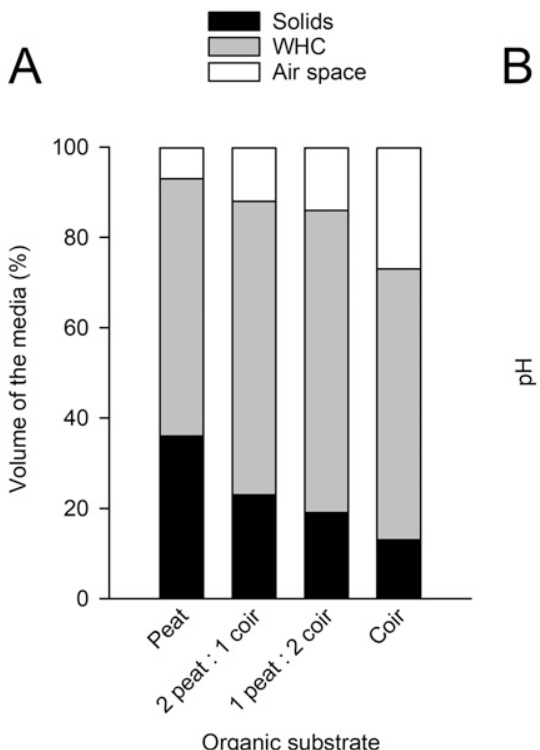

Fig. 2. (A) Physical [solids, water holding capacity (WHC), and air space] and (B) chemical (pH and EC) properties of peat and coir-based media $(\mathrm{n}=16)$. Means are pooled across treatments with different percent perlite in the media $(0 \%, 10 \%, 20 \%$, or $30 \%$, by volume). Spearman Rank Order correlations indicate that percent solids were positively related to the relative proportion of peat in the media $(\rho=$ $0.73)$, while air space, $\mathrm{pH}$, and $\mathrm{EC}$ were negatively related to the relative proportion of peat $(\rho=-0.85,-0.91$, and -0.78 , respectively) $(P<0.05)$.
Temperature and relative humidity were measured near the top of the canopy of the plants using a shielded temperature/humidity sensor (Humitter 50 YC; Vaisala, Woburn, MA). Solar radiation $\left(\mathrm{kW} \cdot \mathrm{m}^{-2}\right)$ was also measured using a light meter (LI200X-L; LI-COR Environmental, Lincoln, NE) and converted to photosynthetically active radiation $\left(P A R ; \mathrm{mol} \cdot \mathrm{m}^{-2} \cdot \mathrm{d}^{-1}\right)($ Biggs, 1986). Readings from each sensor were recorded every 15 min using a data logger (CR10X; Campbell Scientific, Logan, UT). Mean daily temperature averaged $22.8{ }^{\circ} \mathrm{C}$ and ranged from 14.8 to $28.5^{\circ} \mathrm{C}$. Relative humidity and $P A R$ averaged $59 \%$ and $28 \mathrm{~mol} \cdot \mathrm{m}^{-2} \cdot \mathrm{d}^{-1}$, respectively.

Each pot was fertigated daily after transplanting with $100 \mathrm{~mL}$ of modified Hoagland's nutrient solution (Hoagland and Arnon, 1938). The solution was adjusted to $\mathrm{pH} 5.2$ with sulfuric acid and contained $5.5 \mathrm{~mm} \mathrm{~N}$ from $\left(\mathrm{NH}_{4}\right)_{2} \mathrm{SO}_{4}$, and $\left(\mathrm{NH}_{4}\right)_{2} \mathrm{HPO}_{4}+1.14 \mathrm{~mm} \mathrm{~N}$ as a chelating agent used to deliver $\mathrm{Ca} ; 0.51 \mathrm{~mm}$ $\mathrm{P}$ from $\left(\mathrm{NH}_{4}\right)_{2} \mathrm{HPO}_{4} ; 3.07 \mathrm{~mm} \mathrm{~K}$ from $\mathrm{K}_{2} \mathrm{SO}_{4}$; $2 \mathrm{~mm} \mathrm{Ca}$ from chelated $\mathrm{Ca}$ product (ProNatural Calcium; Wilbur Ellis, Aurora, CO); $0.74 \mathrm{~mm} \mathrm{Mg}$ from $\mathrm{MgSO}_{4} * 7 \mathrm{H}_{2} \mathrm{O} ; 25 \mu \mathrm{M} \mathrm{Fe}$ from Fe-DTPA; $25 \mu \mathrm{M}$ B from $\mathrm{H}_{3} \mathrm{BO}_{3} ; 3 \mu \mathrm{M}$ $\mathrm{Mn}$ from $\mathrm{MnCl}_{2} * 4 \mathrm{H}_{2} \mathrm{O}$; and $4 \mu \mathrm{M} \mathrm{Zn}$ from $\mathrm{ZnSO}_{4} * 7 \mathrm{H}_{2} \mathrm{O}$. Extra irrigation water was added to maintain drainage at $\approx 25 \%$ of the total volume of solution applied. Plants were also irrigated twice on warm and sunny days, as needed, to prevent the pots from drying out.

Measurements. A 100-g air-dry sample of media from each treatment was submitted to a commercial laboratory (Soil Control Laboratory, Watsonville, CA) for initial analysis (before planting) of physical and chemical properties, including bulk density, porosity, particle size distribution, $\mathrm{pH}$, electrical conductivity (EC), organic matter content, available $\mathrm{N}\left(\mathrm{NH}_{4}-\mathrm{N}\right.$ and $\left.\mathrm{NO}_{3}-\mathrm{N}\right)$, and other extractable nutrients $\left(\mathrm{P}, \mathrm{K}, \mathrm{Ca}, \mathrm{Mg}, \mathrm{SO}_{4}-\mathrm{S}\right.$, $\mathrm{B}, \mathrm{Cu}, \mathrm{Fe}, \mathrm{Mn}, \mathrm{Zn}, \mathrm{Na}$, and $\mathrm{Cl}$ ). See Kingston et al. (2017) for a description of the procedures used for each analysis.

Leachate was collected every 2 weeks after transplanting, using a modified pourthrough method (Wright, 1986). To do so, pots were irrigated with $67 \mathrm{~mL}$ of water at $\approx 1 \mathrm{~h}$ after fertigation, and $50 \mathrm{~mL}$ of leachate was collected from saucers placed under the pots. Samples from three pots per treatment were then stored in glass vials at $3{ }^{\circ} \mathrm{C}$ and later analyzed for $\mathrm{pH}$ and $\mathrm{EC}$ using a $\mathrm{pH} / \mathrm{ion} /$ conductivity meter (model SevenGo Duo pro with an InLab Expert Pro-ISM-IP67 probe

Table 1. Extractable nutrients in peat- and coir-based media. ${ }^{z}$

\begin{tabular}{|c|c|c|c|c|c|c|c|c|c|c|c|c|c|}
\hline \multirow[b]{2}{*}{ Organic substrate } & \multicolumn{13}{|c|}{ Extractable nutrients $\left(\mathrm{mg} \cdot \mathrm{L}^{-1}\right)$} \\
\hline & $\overline{\mathrm{NH}_{4}-\mathrm{N}}$ & $\mathrm{NO}_{3}-\mathrm{N}$ & $\mathrm{P}$ & $\mathrm{K}$ & $\mathrm{Ca}$ & $\mathrm{Mg}$ & $\mathrm{SO}_{4}-\mathrm{S}$ & $\mathrm{B}$ & $\mathrm{Cu}$ & $\mathrm{Fe}$ & $\mathrm{Mn}$ & $\mathrm{Zn}$ & $\mathrm{Na}$ \\
\hline$\overline{\text { Peat }}$ & 1.8 & 13.4 & 2 & 106 & 1081 & 563 & 10 & 0.3 & 0.2 & 102 & 23 & 3.0 & 116 \\
\hline 2 peat: 1 coir & 2.0 & 1.8 & 11 & 864 & 938 & 459 & 10 & 0.4 & 0.4 & 80 & 16 & 2.9 & 249 \\
\hline 1 peat: 2 coir & 1.6 & 0.8 & 23 & 1469 & 778 & 377 & 11 & 0.6 & 0.5 & 55 & 12 & 2.9 & 372 \\
\hline Coir & 1.5 & 0.5 & 34 & 1829 & 535 & 259 & 12 & 0.7 & 0.5 & 19 & 10 & 5.0 & 448 \\
\hline Spearman's $\rho^{y}$ & 0.64 & 0.81 & -0.97 & -0.88 & 0.81 & 0.92 & NS & -0.93 & -0.90 & 0.95 & 0.94 & NS & -0.98 \\
\hline
\end{tabular}

${ }^{\mathrm{z}}$ Measured before planting using a 100 -g sample of each media $(\mathrm{n}=16)$. Means are pooled across treatments with different percentages of perlite in the media $(0 \%$, $10 \%, 20 \%$, or $30 \%$, by volume).

${ }^{\mathrm{y}}$ Values indicate a significant positive or negative relationship between nutrient concentration and the relative proportion of peat in the media $(P \leq 0.05)$. NS $=$ nonsignificant. 
for $\mathrm{pH}$, and an InLab 738 ISM conductivity probe for EC; Mettler-Toledo, Columbus, $\mathrm{OH}$ ). The vials were placed in a water bath during the measurements and maintained at $25^{\circ} \mathrm{C}$.

The plants were harvested destructively at $95 \mathrm{~d}$ after transplanting. Five additional plants were harvested before transplanting (day 0 ). The shoots were cut off at the surface of the media on each date, rinsed with distilled water, and separated into stems (canes) and leaves. The media was then removed from the pots (or plug trays at day 0 ) and washed under running water to collect the roots. Each plant component was oven-dried at $60{ }^{\circ} \mathrm{C}$, weighed, and ground to pass a $1-\mathrm{mm}$ screen. About $1 \mathrm{~g}$ of the ground samples was analyzed for $\mathrm{N}$ using a combustion analyzer (TruSpec CN; Leco Corp., St. Joseph, $\mathrm{MI})$, and another $1 \mathrm{~g}$ of each sample was digested in a microwave using $70 \%(\mathrm{v} / \mathrm{v})$ nitric acid and analyzed for $\mathrm{P}, \mathrm{K}, \mathrm{S}, \mathrm{Ca}, \mathrm{Mg}, \mathrm{Fe}, \mathrm{B}, \mathrm{Cu}, \mathrm{Mn}, \mathrm{Zn}$, and $\mathrm{Na}$ using an inductively coupled plasmaoptical emission spectrometer (Perkin Elmer Optima 3000DV; Wellesley, MA) (Gavlak et al., 2005; Jones and Case, 1990). Reference standard apple [Malus Xsylvestris (L.) Mill. var. domestica (Borkh.) Mansf.] leaves (no. 151, National Institute of Standards and Technology) were included in each set of samples to ensure accuracy of the instruments and digestion procedures. Total content of each nutrient in the plants was calculated by multiplying tissue dry weight by the concentration of the nutrient and taking the sum of each tissue (leaves, stems, and roots). Total uptake of each nutrient was then calculated as the difference between total content at 0 and $95 \mathrm{~d}$ after transplanting.

Data analysis. All data were analyzed using Statistica analytical software (ver. 13; Dell, Inc., Tulsa, OK). Spearman Rank Order correlation $(\rho)$ was used to estimate correlative relationships between physical and chemical properties of the media mixtures with the various ingredient proportions and plant dry weight $(\mathrm{n}=$ 16). Total dry weight was evaluated by analysis of variance (ANOVA). Cultivar and the percentage of perlite and peat in the media were treated as fixed effects. The percentage of coir in the media was inversely related to the percentage of peat, and therefore was not included in the model. Total uptake of each nutrient in the plants was also evaluated by ANOVA, but in this case, total dry weight was used as a covariate to account for differences in plant growth among the treatments (Scagel et al., 2008). Likewise, leachate volume was used as a covariate in the analysis of leachate $\mathrm{pH}$ and EC. Contrast analysis was used to examine significant responses of the variables to the percentage of peat or perlite in the media. To meet statistical assumptions for variance of residuals and normal distribution, data on total uptake of $\mathrm{B}$ and $\mathrm{Cu}$ in the plants were transformed using a natural logarithm and back-transformed for presentation.

\section{Results and Discussion}

Initial physical and chemical properties of the media. Perlite increased bulk density and the proportion of larger particles in the media (Fig. 1). It also had a slight effect on the concentration of extractable $\mathrm{Zn}$ in the media $(5.1,3.1,2.9$, and $2.7 \mathrm{ppm} \mathrm{Zn}$ with $0 \%$, $10 \%, 20 \%$, and $30 \%$ perlite; $\rho=-0.55$ ) but had no effect on air space, WHC, pH, EC, or concentration of the other nutrients in the media, including available $\mathrm{NH}_{4}-\mathrm{N}$ and $\mathrm{NO}_{3}-$ $\mathrm{N}$ and extractable $\mathrm{P}, \mathrm{K}, \mathrm{Ca}, \mathrm{Mg}, \mathrm{SO}_{4}-\mathrm{S}, \mathrm{B}$, $\mathrm{Cu}, \mathrm{Mn}$, or $\mathrm{Na}(P>0.05)$. Usually, coarse substrates such as perlite increase porosity and drainage and reduce WHC of the media (Fields et al., 2014; Kingston et al., 2017). However, Rhie and Kim (2017) found that it took at least $40 \%$ perlite to reduce WHC in substrate mixes with coir dust. Fields et al. (2014) suggested that small particles in the media can settle into large pore spaces in perlite and, thereby, reduce potential differences in porosity and WHC.

Water holding capacity was also unaffected by the organic substrates, which averaged $62 \%$, regardless of the proportion of peat or coir in the mix (Fig. 2A). However, coir increased air space, $\mathrm{pH}$, and $\mathrm{EC}$ relative to peat (Fig. 2A and B) and resulted in higher concentrations of $\mathrm{P}, \mathrm{K}, \mathrm{B}, \mathrm{Cu}$, and $\mathrm{Na}$ and lower concentrations of $\mathrm{NH}_{4}-\mathrm{N}, \mathrm{NO}_{3}-\mathrm{N}, \mathrm{Ca}$, $\mathrm{Mg}, \mathrm{Fe}$, and $\mathrm{Mn}$ (Table 1). Despite rinsing the substrate before use, coir also resulted in much higher concentrations of $\mathrm{Cl}$, particularly when little or no perlite was added to the media (Fig. 3). Salinity is variable among different sources of coir and, therefore, can be problematic when coir is used as a primary substrate for container production (Konduru et al., 1999).

Leachate $\mathrm{pH}$ and EC. The $\mathrm{pH}$ and EC of leachate from the pots decreased over time $(P<0.0001)$ and were affected by perlite $(P=$ $0.0250)$ and peat and coir $(P<0.0001)$ in the mix. However, neither were affected by cultivar or interactions among the treatments. On average, $\mathrm{pH}$ and $\mathrm{EC}$ were lower with $30 \%$ perlite than with $20 \%$ perlite or less (Fig. 4A) and were higher with increasing amounts of coir in the mix (Fig. 4B). In most treatments, $\mathrm{pH}$ was within a range of 4.5-5.5, which is recommended for northern and southern highbush blueberry (Retamales and Hancock, 2018). However, $\mathrm{pH}$ dropped to 4.0 with $30 \%$ perlite in the mix and to 3.8 with peat. Aluminum becomes more available at low pH (Bar-Tal et al., 2019), which could damage the roots and impede plant uptake of immobile nutrients such as $\mathrm{NH}_{4}-\mathrm{N}, \mathrm{P}$, and $\mathrm{Fe}$ (Marschner, 2012). Leachate EC, on the other hand, was somewhat high initially in many treatments but, within a few weeks, dropped to $<2 \mathrm{dS} \cdot \mathrm{m}^{-1}$, which is considered safe for salt-sensitive crops such as blueberry (Machado et al., 2014).

Plant growth. Total dry weight of the plants was significantly affected by a three-way interaction among cultivar, perlite, and the

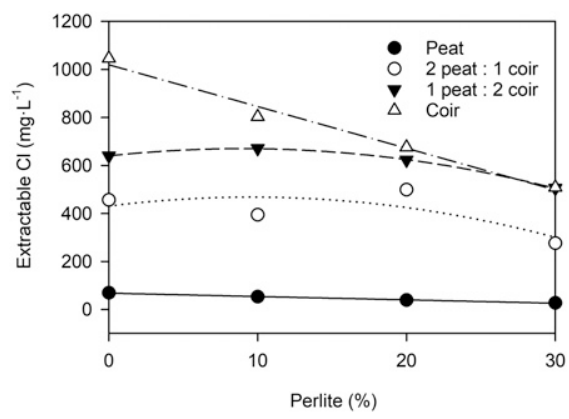

Fig. 3. Concentration of extractable $\mathrm{Cl}$ in media with $0 \%, 10 \%, 20 \%$, or $30 \%$ perlite, by volume, and different organic substrates, including peat, 2 peat: 1 coir, 1 peat: 2 coir, or coir $(n=16)$. Spearman Rank Order correlations indicate that the concentration of $\mathrm{Cl}$ was negatively related to percent perlite $(\rho=-0.58)$ and the relative proportion of peat $(\rho=-0.88)$ in the media $(P<0.05)$.
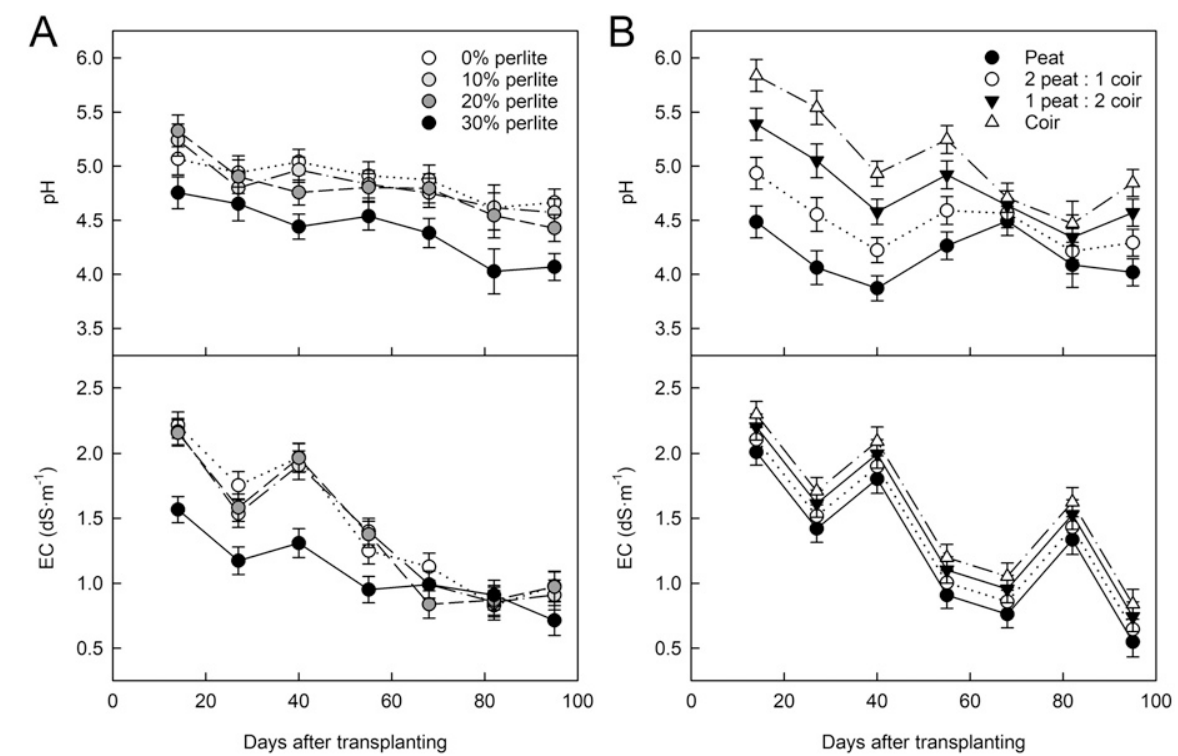

Fig. 4. Leachate $\mathrm{pH}$ and $\mathrm{EC}$ from pots of 'Jewel' and 'Liberty' blueberry grown in media containing $0 \%$, $10 \%, 20 \%$, or $30 \%$ perlite, by volume, and different organic substrates, including peat, 2 peat: 1 coir, 1 peat: 2 coir, or coir. Means are pooled across (A) cultivars and peat:coir ratios or (B) cultivars and percent perlite in the media. Error bars represent $95 \%$ confidence intervals. 
proportion of peat and coir in the media $(P=$ 0.0158 ). In terms of dry weight, 'Liberty' grew best in pure peat and had progressively less growth as more coir or perlite was added to the media (Fig. 5A). 'Jewel' also had less growth with more perlite in the media, but unlike 'Liberty', it was unaffected by the proportion of peat and coir in the mix (Fig. 5B). Apparently, 'Liberty' was sensitive to high $\mathrm{pH}$ and/ or high salinity in the coir, whereas 'Jewel' was not. In general, southern highbush cultivars such as Jewel appear to be more tolerant to high salinity than northern highbush cultivars such as Liberty (J. Umble, personal communication). However, it is unclear why both cultivars had a negative response to perlite. As mentioned, perlite had no measurable effect on porosity, WHC, or essential nutrients in the media. Bunt (1983) observed that perlite reduced easily available water (defined as the quantity of water released at -1 to $-5 \mathrm{kPa}$ ) in peat, particularly when used at volumes $>25 \%$ in the mix. Perhaps perlite led to water stress between irrigations in the present study. Water stress is frequently observed at relatively high water potentials in potted plants due to a strong increase in hydraulic resistance at the interface between the roots and the growing media (Allaire-Leung et al., 1999; Caron et al., 1998; da Silva et al., 1993; Heiskanen, 1995a, 1995b; Naasz et al., 2005, 2008). Adding large particles of perlite would likely exacerbate this problem and further increase hydraulic resistance between the roots and the media (Londra et al., 2018).

In both cultivars, total dry weight of the plants was positively correlated with initial measures of organic matter content $(\rho=0.52$ in 'Jewel' and 'Liberty') and total available $\mathrm{N}$ $(\rho=0.60$ in 'Jewel' and 0.68 in 'Liberty') in the media. Total dry weight was also positively correlated with small particle sizes in the media ( $0-2 \mathrm{~mm}, \rho=0.69)$ in 'Jewel' and was negatively correlated with the concentration of $\mathrm{Cu}, \mathrm{Na}$, and $\mathrm{Cl}$ in the media in 'Liberty' ( $\rho \geq-0.51)$.

Nutrient uptake. Total uptake of numerous nutrients in the plants was affected by cultivar and the proportion of peat and coir in the media (Table 2). However, total uptake of each nutrient was unaffected by the percent perlite in the media or, with the exception of
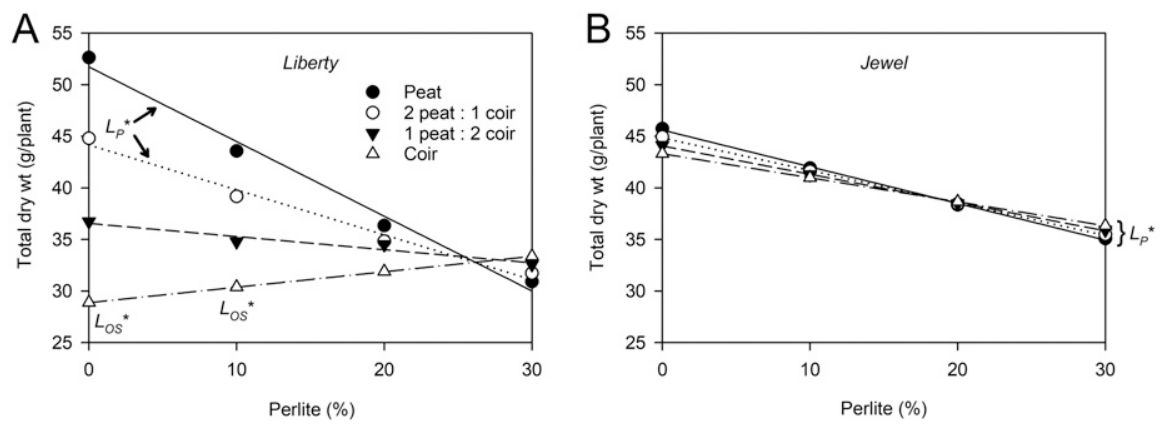

Fig. 5. Effect of media composition on total dry weight of (A) 'Liberty' and (B) 'Jewel' blueberry. The plants were grown for $95 \mathrm{~d}$ in media with $0 \%, 10 \%, 20 \%$, or $30 \%$ perlite, by volume, and different organic substrates, including peat, 2 peat: 1 coir, 1 peat: 2 coir, or coir. $L_{P}$ indicates the response to perlite in the media is linear within a given peat:coir ratio, while $L_{O S}$ indicates the response to the relative proportion of peat in the media is linear within a given percentage of perlite $(P \leq 0.05)$.
Mn, by interactions among the treatments. On average, both cultivars took up more $\mathrm{N}, \mathrm{P}, \mathrm{Mg}$, and $\mathrm{S}$ and less $\mathrm{K}, \mathrm{B}, \mathrm{Zn}$, and Na when they were grown in substrates with more peat than coir. Handreck (1993) observed that $\mathrm{N}$ availability declined in coir and attributed it to $\mathrm{N}$ immobilization by the substrate. In contrast, adding more peat to the media increased $\mathrm{N}$ in the present study, including availability of $\mathrm{NH}_{4}$ $\mathrm{N}$ (Table 1), which is considered preferable over $\mathrm{NO}_{3}-\mathrm{N}$ in blueberry (Rosen et al., 1990). However, peat reduced the amount of $\mathrm{P}$ in the substrate and had no effect on $\mathrm{S}$ or $\mathrm{Zn}$. In this case, greater $\mathrm{P}$ uptake in peat may have been a function of the $\mathrm{pH}$ of the media (Marschner, 2012). As mentioned, leachate $\mathrm{pH}$ was initially lower with peat (Fig. 4B), and low $\mathrm{pH}$ can increase the availability of $\mathrm{P}$ in substrate (Altland and Buamscha, 2008). Peat also reduced $\mathrm{pH}$ and increased uptake of $\mathrm{P}$ relative to coir in our previous study on 'Snowchaser' blueberry (Kingston et al., 2017).

Much like $\mathrm{N}$, differences in uptake of other nutrients, including $\mathrm{K}, \mathrm{Mg}, \mathrm{B}$, and $\mathrm{Na}$, appeared to be related to the initial concentration of each in the media. Plant uptake of these nutrients is driven largely by the concentration in the root zone (Silber et al., 2003). For example, peat contained much less $\mathrm{K}$ than coir in the present study (Table 1). In fact, the initial concentration of $\mathrm{K}$ in peat-based media was in a range considered deficient for soil-grown blueberry plants (i.e., $<150$ ppm K; Hart et al., 2006). The initial concentration of $\mathrm{K}$ in coir, on the other hand, was very high. Consequently, $\mathrm{K}$ uptake was greater when the plants were grown with coir than with peat (Table 2). Clearly, the use of coir in the media would reduce the need for $\mathrm{K}$ fertilizer initially, but it might increase the need for $\mathrm{Ca}$ and $\mathrm{Mg}$ (Handreck, 1993). High levels of $\mathrm{K}$ in either soil or potting media have been shown to limit uptake of $\mathrm{Ca}$ and $\mathrm{Mg}$ in many plants, including blueberry (Kingston, 2017; Strik et al., 2019). In the present study, $\mathrm{Mg}$ uptake was inversely related to the initial

Table 2. Nutrient uptake by 'Liberty' and 'Jewel' blueberry grown for $95 \mathrm{~d}$ in media with $0 \%, 10 \%, 20 \%$, or $30 \%$ perlite, by volume, in combination with different organic substrates, including peat, 2 peat: 1 coir, 1 peat: 2 coir, or coir $(n=5)$.

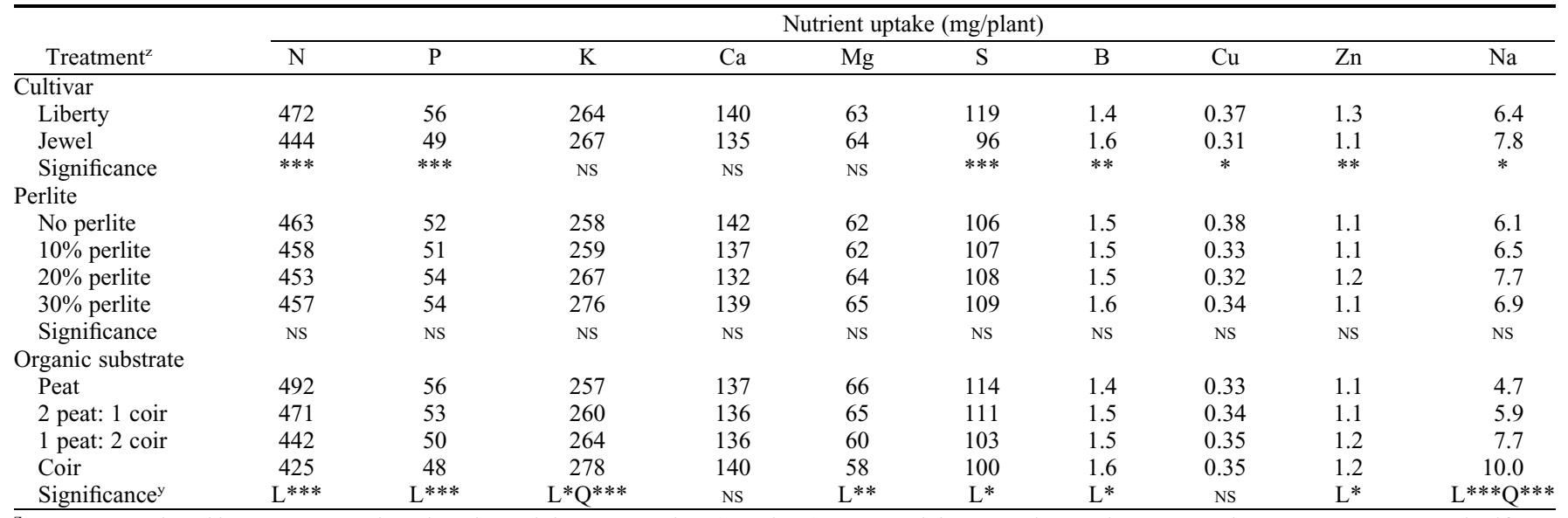

${ }^{\mathrm{z}}$ Data were analyzed by ANCOVA using plant dry weight as a covariate (see Fig. 5). Two- and three-way interactions among the treatments were nonsignificant $(P>0.05)$

${ }^{\mathrm{y}} \mathrm{L}$ and $\mathrm{Q}$ indicate the response to the relative proportion of peat in the media is linear or quadratic.

Ns, $* * *, * * *$ Nonsignificant or significant at $P<0.05,0.01$, or 0.001 , respectively. 

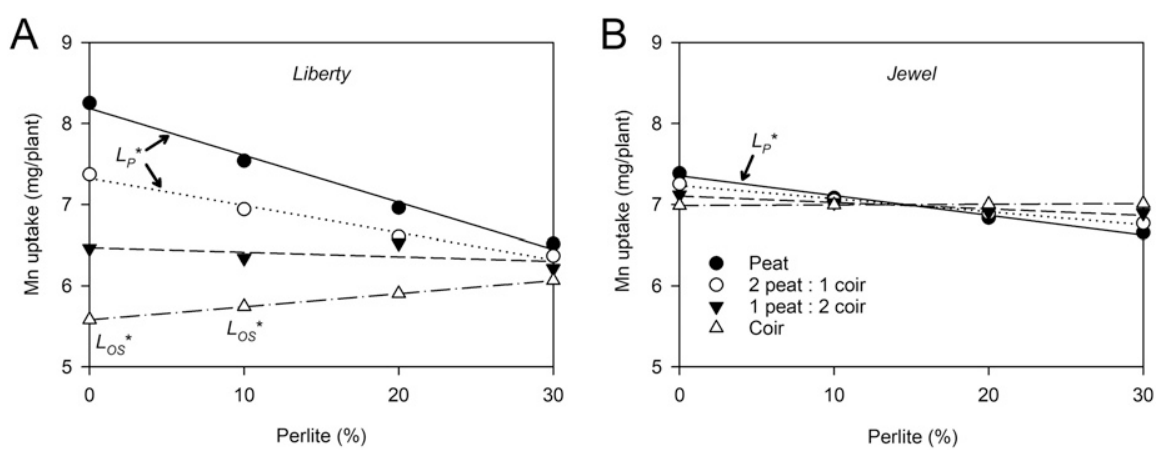

Fig. 6. Effect of media composition on uptake of Mn in (A) 'Liberty' and (B) 'Jewel' blueberry. Plants were grown for $95 \mathrm{~d}$ in media containing $0 \%, 10 \%, 20 \%$, or $30 \%$ perlite, by volume, and different organic substrates, including peat, 2 peat: 1 coir, 1 peat: 2 coir, or coir. $L_{P}$ indicates the response to perlite in the media is linear within a given peat:coir ratio, while $L_{O S}$ indicates the response to the relative proportion of peat in the media is linear within a given percentage of perlite $(P \leq 0.05)$.

Table 3. Concentration of $\mathrm{Na}$ in the leaves, canes, and roots of 'Liberty' and 'Jewel' blueberry grown for $95 \mathrm{~d}$ in media with $0 \%, 10 \%, 20 \%$, or $30 \%$ perlite, by volume, in combination with different organic substrates, including peat, 2 peat: 1 coir, 1 peat: 2 coir, or coir $(n=5)$.

\begin{tabular}{|c|c|c|c|}
\hline \multirow[b]{2}{*}{ Treatment $^{z}$} & \multicolumn{3}{|c|}{$\mathrm{Na}$ concn (ppm) } \\
\hline & Leaves & Canes & Roots \\
\hline \multicolumn{4}{|l|}{ Cultivar } \\
\hline Liberty & 121 & 346 & 354 \\
\hline Jewel & 130 & 276 & 351 \\
\hline Significance & NS & $* *$ & NS \\
\hline \multicolumn{4}{|l|}{ Perlite } \\
\hline No perlite & 77 & 276 & 327 \\
\hline $10 \%$ perlite & 117 & 292 & 340 \\
\hline $20 \%$ perlite & 207 & 358 & 376 \\
\hline $30 \%$ perlite & 101 & 318 & 368 \\
\hline Significance $^{y}$ & $Q^{*}$ & NS & NS \\
\hline \multicolumn{4}{|l|}{ Organic substrate } \\
\hline Peat & 74 & 199 & 264 \\
\hline 2 peat: 1 coir & 90 & 273 & 302 \\
\hline 1 peat: 2 coir & 140 & 327 & 358 \\
\hline Coir & 197 & 445 & 487 \\
\hline Significance $^{\mathrm{y}}$ & $\mathrm{L}^{*}$ & $\mathrm{~L}^{* * *}$ & $\mathrm{~L}^{* * *}$ \\
\hline
\end{tabular}

${ }_{\mathrm{z}}$ Interactions among cultivar, perlite, and organic substrate are nonsignificant.

${ }^{\mathrm{y}} \mathrm{L}$ and $\mathrm{Q}$ indicate the response to percent perlite or the relative proportion of peat in the media is linear or quadratic.

NS, *,**,***Nonsignificant or significant at $P<$ $0.05,0.01$, or 0.001 , respectively.

concentration of $\mathrm{K}$ in the media and was positively correlated with the initial concentration of $\mathrm{Mg}$ in the media, which was greater in peat than in coir.

Manganese was the only nutrient in which uptake was affected by an interaction among cultivar, perlite, and the proportion of peat and coir in the media $(P=0.0108)$. 'Liberty' took up progressively more $\mathrm{Mn}$ when the plants were grown in media with more peat and took up progressively less Mn when they were grown in media with more perlite (Fig. 6A). 'Jewel' also took up slightly less Mn with more perlite in the media, but in this case, it was only in peat, and uptake was unaffected by the proportion of peat and coir in the mix (Fig. 6B). Any differences in uptake were likely related to $\mathrm{pH}$ of the media. Typically, Mn uptake increases as $\mathrm{pH}$ declines in soil or growing media (Marschner, 2012). In our case, $\mathrm{pH}$ was lower in media with less perlite and more peat (Fig. 4). However, the concentration of $\mathrm{Mn}$ in recently expanded leaf tissue was similar among treatments (131-167 $\mathrm{ppm})$ and well within the range recommended for northern highbush blueberry (30-350 ppm; Hart et al., 2006).

The effect of the media on Na uptake was particularly noteworthy. Sodium uptake was higher in 'Jewel' than in 'Liberty' and two times greater in coir than in peat (Table 2). Plants grown with coir had elevated concentrations of $\mathrm{Na}$ in each plant tissue, including the leaves, canes, and roots (Table 3 ). Interestingly, the plants also had higher concentration of $\mathrm{Na}$ in the leaves when they were grown with perlite. However, leaf $\mathrm{Na}$ was lower with $30 \%$ than with $20 \%$ perlite, and there was no evidence of salt damage (e.g., marginal leaf necrosis) in any treatment. Addition of high amounts of perlite can dilute salts such as $\mathrm{Na}$ in the media (Rhie and Kim, 2017). Muralitharan et al. (1992) observed that $>200 \mathrm{ppm} \mathrm{Na}$ in the leaves was needed to cause damage in 'Bluecrop' northern highbush blueberry. Salt sensitivity has also been reported in rabbiteye blueberry ( $V$. virgatum Aiton) but at much higher concentrations of leaf $\mathrm{Na}(>700 \mathrm{ppm})$ than observed in northern highbush blueberry (Spiers, 1983).

\section{Conclusion}

In most cases, adding perlite to the media resulted in less plant growth in highbush blueberry. However, perlite had little effect on nutrient composition of the media or on plant nutrient uptake. This suggests that the influence of perlite on plant growth was largely unrelated to plant nutrition and more likely due to its influence on irrigation and water relations of the media. In contrast, peat increased plant growth relative to coir in one of the two cultivars tested, which was apparently due to its effect on plant nutrition and salinity in the media. Peat contained much less salt than the coir used in the study and improved plant uptake of nutrients such as N, $\mathrm{P}, \mathrm{Mg}$, and S. Currently, most substrate production of blueberry is done in arid regions such as southern California, Mexico, Spain, and Portugal. Unless reverse osmosis water is used, irrigation water quality is often high in salts such as $\mathrm{NaCl}$ and carbonates and bicarbonates in these locations ( $\mathrm{J}$. Umble, personal communication). Coir would compound this problem by contributing to salinity. The next step is to evaluate the long-term effects of different substrates on fruit production and quality in highbush blueberry.

\section{Literature Cited}

Alkan, M. and M. Doğan. 1998. Surface titrations of perlite suspensions. J. Colloid Interface Sci. 207:90-96.

Allaire-Leung, S.E., J. Caron, and L.E. Parent. 1999. Changes in physical properties of peat substrates during plant growth. Can. J. Soil Sci. 79:137-139.

Altland, J.E. and M.G. Buamscha. 2008. Nutrient availability from douglas fir bark in response to substrate $\mathrm{pH}$. HortScience 43:478-483.

Bar-Tal, A., U.K. Saha, M. Raviv, and M. Tuller. 2019. Inorganic and synthetic organic components of soilless culture and potting mixes, p. 259-301. In: M. Raviv, J.H. Lieth, and A. Bar-Tal (eds.). Soilless culture: Theory and practice. 2nd ed. Academic Press, San Diego, CA.

Biggs, W.W. 1986. Radiation measurement, p. 3-20. In: W.G. Gensler (ed.). Advanced agricultural instrumentation. Martinus Nijhoff, Dordrecht, The Netherlands.

Bilderback, T.E., S.L. Warren, J.S. Owen, and J.P. Albano. 2005. Healthy substrates need physicals too! HortTechnology 15:747-751.

Brazelton, C. 2017. An overview of global blueberry in 2016. 2017 International Blueberry Organization Summit, Qujing City, China. 27 Aug. 2019. <https://www.internationalblueberry.org/ 2017/09/29/an-overview-of-global-blueberryproduction-in-2016/>.

Bugbee, G.J. and C.R. Frink. 1986. Aeration of potting media and plant growth. Soil Sci. $141: 438-441$.

Bunt, A.C. 1983. Physical properties of mixtures of peats and minerals of different particle size and bulk density for potting substrates. Acta Hort. 150:143-154.

Burés, S., M.C. Gago, and F.X. Martinez. 1997. Water characterization in granular materials. Acta Hort. 450:389-396.

Caron, J., H.L. Xu, P.Y. Bernier, I. Duchesne, and P. Tardif. 1998. Water availability in three artificial substrates during Prunus $\times$ cystena growth: Variable threshold values. J. Amer. Soc. Hort. Sci. 123:931-936.

da Silva, F.F., R. Wallach, and Y. Chen. 1993. Hydraulic properties of sphagnum peat moss and tuff (scoria) and their potential effects on water availability. Plant Soil 154:119-126.

Fields, J.S., W.C. Fonteno, B.E. Jackson, J.L. Heitman, and J.S. Owen. 2014. Hydrophysical properties, moisture retention, and drainage profiles of wood and traditional components for greenhouse substrates. HortScience 49:827-832.

Gavlak, R., D. Horneck, and R.O. Miller. 2005. Soil, plant and water reference methods for the western region. 3rd ed. Western Region Extension Publication (WREP-125). WERA-103 Technical Committee. 30 Aug. 2019. <http:// www.naptprogram.org/files/napt/westernstatesmethod-manual-2005.pdf $>$

Grillas, S., M. Lucas, E. Bardopoulou, S. Sarafopoulos, and M. Voulgari. 2001. Perlite based soilless culture systems: Current commercial applications and prospects. Acta Hort. 548: 105-114. 
Handreck, K.A. 1993. Properties of coir dust, and its use in the formulation of soilless potting media. Commun. Soil Sci. Plant Anal. 24:349363.

Hart, J.M., B.C. Strik, L. White, and W. Yang. 2006. Nutrient management for blueberries in Oregon. Ore. St. Univ. Ext. Serv. Publ. EM 8918.

Heiskanen, J. 1995a. Physical properties of twocomponent growth media based on sphagnum peat and their implications for plant-available water and aeration. Plant Soil 172:45-54.

Heiskanen, J. 1995b. Water status of sphagnum peat and a peat-perlite mixture in containers subjected to different irrigation regimes. HortScience 30:281-284.

Hoagland, D.R. and D.I. Arnon. 1938. The waterculture method for growing plants without soil. University of California, College of Agriculture, Agricultural Experiment Station, Berkeley, CA. Circular 347:1-39.

Jones, J.B. and V.W. Case. 1990. Sample, handling, and analyzing plant tissue samples, p. 389-427. In: R.L. Westerman (ed.). Soil testing and plant analysis. 3rd ed. Soil Sci. Soc. Amer., Madison, WI.

Kingston, P.H. 2017. Substrate production of blueberry: Evaluation of soilless media and potassium and nitrogen fertility on growth and nutrition. Oregon State University, Corvallis, MS Thesis. 8 Sept. 2019. <https://ir.library. oregonstate.edu/concern/graduate_thesis_or_ dissertations $/ 37720 \mathrm{j} 19 \mathrm{~m}>$.

Kingston, P.H., C.F. Scagel, D.R. Bryla, and B.C. Strik. 2017. Suitability of sphagnum peat moss, coir, and douglas fir bark as soilless substrates for container production of highbush blueberry. HortScience 52:1692-1699.

Konduru, S., M.R. Evans, and R.H. Stamps. 1999. Coconut husk and processing effects on chem- ical and physical properties of coconut coir dust. HortScience 34:88-90.

Londra, P.A. 2010. Simultaneous determination of water retention curve and unsaturated hydraulic conductivity of substrates using a steady-state laboratory method. HortScience 45:1106-1112.

Londra, P.A., A.T. Paraskevopoulou, and M. Psychoyou. 2012. Evaluation of water-air balance of various substrates on begonia growth HortScience 47:1153-1158.

Londra, P., A. Paraskevopoulou, and M. Psychoyou. 2018. Hydrological behavior of peat- and coirbased substrates and their effect on begonia growth. Water 10:722.

Machado, R.M.A., D.R. Bryla, and O. Vargas. 2014. Effects of salinity induced by ammonium sulfate fertilizer on root and shoot growth of highbush blueberry. Acta Hort. 1017:406-414.

Mann, N.-A. 2015. Intensive berry production using greenhouses, substrates and hydroponics. Is this the way forward? Nuffield Australia Project No. 1415. Nuffield Australia, Moama, NSW.

Marschner, P. 2012. Marschner's mineral nutrition of higher plants. 3rd ed. Academic Press, San Diego, CA.

Munoz, C., R. Soto, and J. Valenzuela. 1993. Effect of chemical and physical potting media characteristics on growth of container-grown rabbiteye blueberries. Acta Hort. 346:162-172.

Muralitharan, M.S., S. Chandler, and S.R. Van. 1992. Effects of sodium chloride and sodium sulfate on growth and solute composition of highbush blueberry (Vaccinium corymbosum). Funct. Plant Biol. 19:155-164.

Naasz, R., J.C. Michel, and S. Charpentier. 2005. Measuring hysteretic hydraulic properties of peat and pine bark using a transient method. Soil Sci. Soc. Amer. J. 69:13-22.
Naasz, R., J.C. Michel, and S. Charpentier. 2008. Water repellency of organic growing media related to hysteretic water retention properties. Eur. J. Soil Sci. 59:156-165.

Retamales, J.B. and J.F. Hancock. 2018. Blueberries, 2nd ed. CABI, Cambridge, MA.

Rhie, Y.H. and J. Kim. 2017. Changes in physical properties of various coir dust and perlite mixes and their capacitance sensor volumetric water content calibrations. HortScience 52:162-166.

Rosen, C.J., D.L. Allan, and J.J. Luby. 1990. Nitrogen form and solution $\mathrm{pH}$ influence growth and nutrition of two Vaccinium clones. J. Amer. Soc. Hort. Sci. 115:83-89.

Scagel, C.F., G. Bi, L.H. Fuchigami, and R.P. Regan. 2008. Nitrogen availability alters mineral nutrient uptake and demand in container-grown deciduous and evergreen Rhododendron. J. Environ. Hort. 26:177-187.

Silber, A., G. Xu, I. Levkovitch, S. Soriano, A. Bilu, and R. Wallach. 2003. High fertigation frequency: The effects on uptake of nutrients, water and plant growth. Plant Soil 253:467477.

Spiers, J.M. 1983. Influence of $\mathrm{N}, \mathrm{K}$ and $\mathrm{Na}$ concentration on growth and leaf element content of 'Tiffblue' rabbiteye blueberry. HortScience 18:223-224.

Strik, B.C., A.J. Vance, D.R. Bryla, and D.M. Sullivan. 2019. Organic production systems in northern highbush blueberry: II. Impact of planting method, cultivar, fertilizer, and mulch on leaf and soil nutrient concentrations and relationships with yield from planting through maturity. HortScience 54:1777-1794.

Wright, R.D. 1986. The pour-through nutrient extraction procedure. HortScience 21:227-229. 